\title{
Propagation of infectious yellow head virus particles prior to cytopathic effect in primary lymphoid cell cultures of Penaeus monodon
}

\author{
Wanchai Assavalapsakul, Duncan R. Smith*, Sakol Panyim \\ Institute of Molecular Biology and Genetics, Mahidol University, Salaya Campus, 25/25 Phuttamonthol Sai 4, Salaya, \\ Nakorn Pathom 73170, Thailand
}

\begin{abstract}
Yellow head virus is a highly pathogenic agent that can cause a fatal disease in several species of penaeid shrimps. Using a primary cell culture and an in vitro quantal assay $\left(\mathrm{TCID}_{50}\right)$, this study sought to determine the propagation profile of yellow head virus after inoculation at a low multiplicity of infection in the lymphoid tissue (oka organ) of Penaeus monodon. Detectable levels of virus were present as early as $24 \mathrm{~h}$ post-inoculation. Maximal viral yields were reached by $4 \mathrm{~d}$ post-infection, approximately $24 \mathrm{~h}$ after the onset of a detectable cytopathic effect, which was normally observable at $3 \mathrm{~d}$ post-inoculation. The methodology provides a useful tool for studying yellow head virus-host-cell interactions.
\end{abstract}

KEY WORDS: Penaeus monodon · Yellow head virus · YHV · Cell culture $\cdot$ Oka organ

Resale or republication not permitted

without written consent of the publisher

Yellow head virus (YHV) is a highly pathogenic agent that causes an acute and often fatal disease in a variety of penaeid shrimps. Susceptible species include Penaeus monodon (Boonyaratpalin et al. 1993), $P$. aztecus, $P$. duorarum, $P$. merguiensis, $P$. setiferus (Flegel 1997, Flegel et al. 1997, Lightner et al. 1998) as well as $P$. stylirostris and $P$. vannamei, although in the latter 2 species the characteristic yellow discoloration of the cephalothorax is not observed (Lu et al. 1994). Infection of $P$. monodon shrimp stocks with YHV has been reported in the SE Asian and Indo-Pacific countries of Thailand (Boonyaratpalin et al. 1993), India (Mohan et al. 1998) and Taiwan (Wang \& Chang 2000), and has caused significant economic loss.

The virus particle is enveloped and contains a positive-sense single-stranded RNA (Tang \& Lightner 1999). The gill and lymphoid oka organ tissues are primary targets for YHV replication (Lu et al. 1995a), and YHV will infect cells of both ectodermal and mesoder- mal origin (Boonyaratpalin et al. 1993). Cellular necrosis has been reported to be widespread in connective tissues, hematopoietic organs and the lymphoid organ, and massive necrosis of circulating hemocytes is characteristic of YHV infection (Boonyaratpalin et al. 1993).

Currently there are no established penaeid cell lines, and therefore primary cell culture techniques have been developed for the growth and analysis of penaeid shrimp viruses, including YHV (Lu et al. 1995b, Chen \& Wang 1999). Explant cell cultures have been obtained from various tissues and organs of the penaeid shrimp, including the lymphoid (oka) organ (Chen \& Kou 1989, Nadala et al. 1993, Hsu et al. 1995, Lu et al. 1995b, Tapay et al. 1995, 1997, Chen \& Wang 1999, Itami et al. 1999, Kasornchandra et al. 1999, Owens \& Smith 1999, West et al. 1999, Wang et al. 2000), the heart (Chen et al. 1986, Chen \& Wang 1999, Owens \& Smith 1999), nerve cord (Nadala et al. 1993, Owens \& Smith 1999), gut (Nadala et al. 1993), hepatopancreas (Owens \& Smith 1999) and gonads (Chen et al. 1986, Luedeman \& Lightner 1992, Nadala et al. 1993, Chen \& Wang 1999, Fraser \& Hall 1999, Owens \& Smith 1999). Primary cell cultures of the lymphoid organ are susceptible to YHV (Lu et al. 1995b, Chen \& Wang 1999) and to white spot syndrome virus (WSSV: Tapay et al. 1997), both of which produce cytopathic effects (CPE) that include 'roundings' of cells and their detachment from the substrate, which occurs as early as $3 \mathrm{~d}$ postinoculation for YHV (Lu et al. 1995b) and 2 d postinoculation for WSSV (Tapay et al. 1997). The present study aimed at determining the virus propagation profile of YHV in a primary cell culture of the oka organ by means of an in vitro quantal assay $\left(\right.$ TCID $\left._{50}\right)$ (Reed \& Muench 1938).

Materials and methods. Cell culture, virus purification, and analyses were carried out as follows: 
Primary lymphoid (oka) cell culture: Primary cell cultures from the lymphoid (oka) organ of Penaeus monodon were established as described by Kasornchandra et al. (1999), except that we used the growth medium (minus shrimp-meat extract) as holding medium and supplemented both growth medium and holding medium with $5 \%(\mathrm{w} / \mathrm{v})$ lactalbumin.

Virus purification: To obtain a source of fresh virus, previously purified YHV was injected directly into the muscle of healthy Penaeus monodon, which were then maintained in seawater at 26 to $28^{\circ} \mathrm{C}$. When the shrimp became moribund, hemolymph was drawn and YHV was purified by urografin gradient ultracentrifugation (Wongteerasupaya et al. 1995).

Nucleic acid extraction and PCR: Nucleic acids were extracted from either $30 \mu \mathrm{l}$ of growth medium or $200 \mu \mathrm{l}$ of hemolymph using TRIzol $^{\oplus}$ LS reagent (Gibco-BRL) according to the manufacturer's recommendations. The presence of YHV was detected by reverse transcriptase-PCR (RT-PCR) using the methodology and primers of Wongteerasupaya et al. (1997), which produce a $135 \mathrm{bp}$ amplicon in the presence of YHV. The presence of WSSV was detected by PCR using the SEMTEST MINI KIT (Ezee Gene, SBBU, Thailand) according to the manufacturer's protocol. This reaction produces a $232 \mathrm{bp}$ amplicon in the presence of WSSV. A positive control for WSSV is included in the kit.

SDS-PAGE and Western blot analysis: Either $40 \mu \mathrm{l}$ of growth medium (after centrifugation at $1500 \mathrm{~g}$ for $15 \mathrm{~min}$ at $4^{\circ} \mathrm{C}$ ) or $1 \mu \mathrm{l}$ of purified virus were loaded onto parallel sodium dodecyl sulfate-polyacrylamide gel electrophoresis (SDS-PAGE) gels. Following electrophoresis, 1 gel was stained with Coomassie Brilliant Blue R-250, while the other was blotted onto a nitrocellulose membrane which was then incubated with a mouse monoclonal antibody specific to the p116 protein of yellow head virus (YHV-monoclonal detection kit; Ezee Gene, SBBU, Thailand) at a dilution of 1:3000 for $2.5 \mathrm{~h}$ at room temperature $\left(25^{\circ} \mathrm{C}\right)$ with gentle agitation. After rinsing 3 times with Tris-buffered saline, the membrane was incubated with a horseradish peroxidase labeled goat anti-mouse (IgG) antibody (Sigma Chemical) at a dilution of 1:3000 at room temperature with gentle agitation on a shaker for $1.5 \mathrm{~h}$. The signal was developed using the ECL Plus Western Blotting Detection Reagent (Amersham Pharmacia Biotech) and exposure to X-ray film for $5 \mathrm{~min}$.

Electron microscopy: Transmission electron microscope examination of the viral stock was essentially as described by Wongteerasupaya et al. (1995), and grids were examined with a JOEL Model JEM-200CX transmission electron microscope with an accelerating voltage of $100 \mathrm{kV}$.
Propagation of $\mathrm{YHV}$ in primary lymphoid cell culture: Primary cell cultures from lymphoid organs were established in $25 \mathrm{~cm}^{2}$ culture flasks. When confluent monolayers were formed, the cell cultures were infected with YHV. Briefly, purified YHV was diluted from $210^{9} \mathrm{TCID}_{50} \mathrm{ml}^{-1}$ to $210^{3} \mathrm{TCID}_{50} \mathrm{ml}^{-1}$ (determined by TCID $_{50}$ assay: see following subsection) with basal medium, passed through a $0.45 \mu \mathrm{m}$ filter and inoculated onto confluent monolayers (containing 2 $10^{6}$ cells) at a multiplicity of infection (MOI) of 0.001 . After infection, $4.5 \mathrm{ml}$ of basal medium was added. Flasks were then incubated at $28 \pm 1^{\circ} \mathrm{C}$ for $8 \mathrm{~d}$ and duplicate $100 \mu \mathrm{l}$ aliquots of culture medium were sampled daily during this time. Each $100 \mu \mathrm{l}$ aliquot was subjected to $\mathrm{TCID}_{50}$ analysis, allowing duplicate determination of viral levels at each time point. The experiment was undertaken in duplicate. Control flasks were inoculated with basal medium only.

In vitro quantal assay $\left(\mathbf{T C I D}_{50}\right)$ : Confluent monolayers of primary cell cultures of the lymphoid organ, established in 96-well tissue-culture plates were used for $\mathrm{TCID}_{50}$ analysis. Half of the $100 \mu \mathrm{l}$ of the aliquots containing YHV was diluted by 10 -fold serial dilutions with basal medium, $50 \mu \mathrm{l}$ of each dilution was inoculated into each of 8 parallel wells and plates and incubated at room
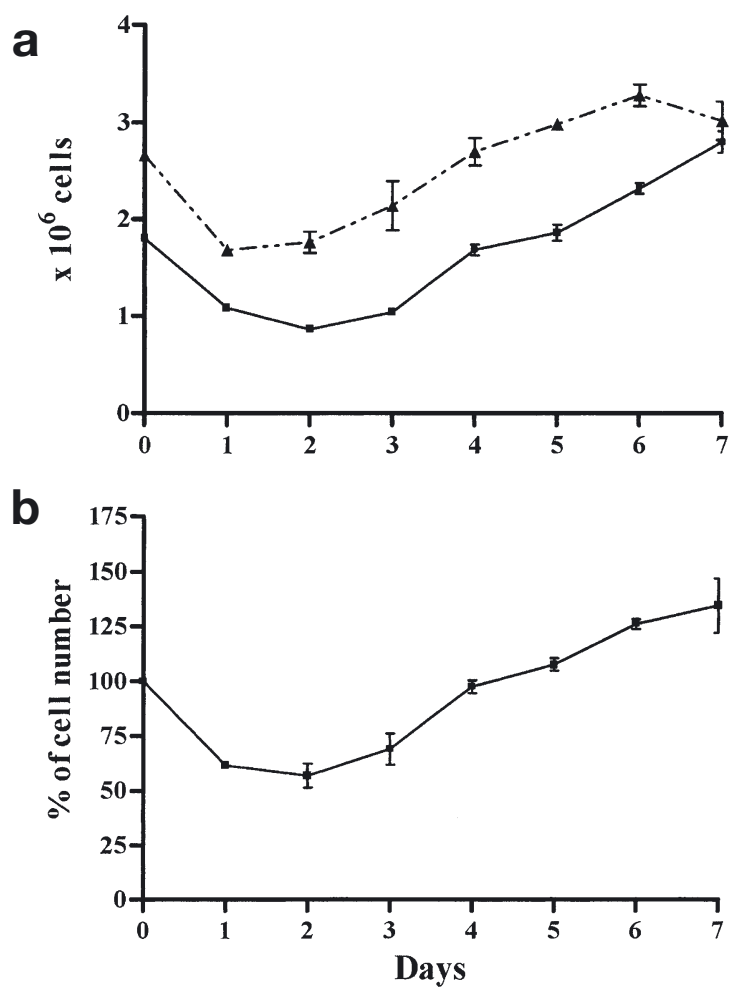

Fig. 1. Penaeus monodon. Growth curves of primary cell cultures of oka organ. (a) Mean $( \pm \mathrm{SD}, \mathrm{n}=2)$ cell numbers in 2 independent experiments; (b) mean $( \pm \mathrm{SEM}, \mathrm{n}=2)$ growth of primary cell cultures as percentage of cells initially seeded 

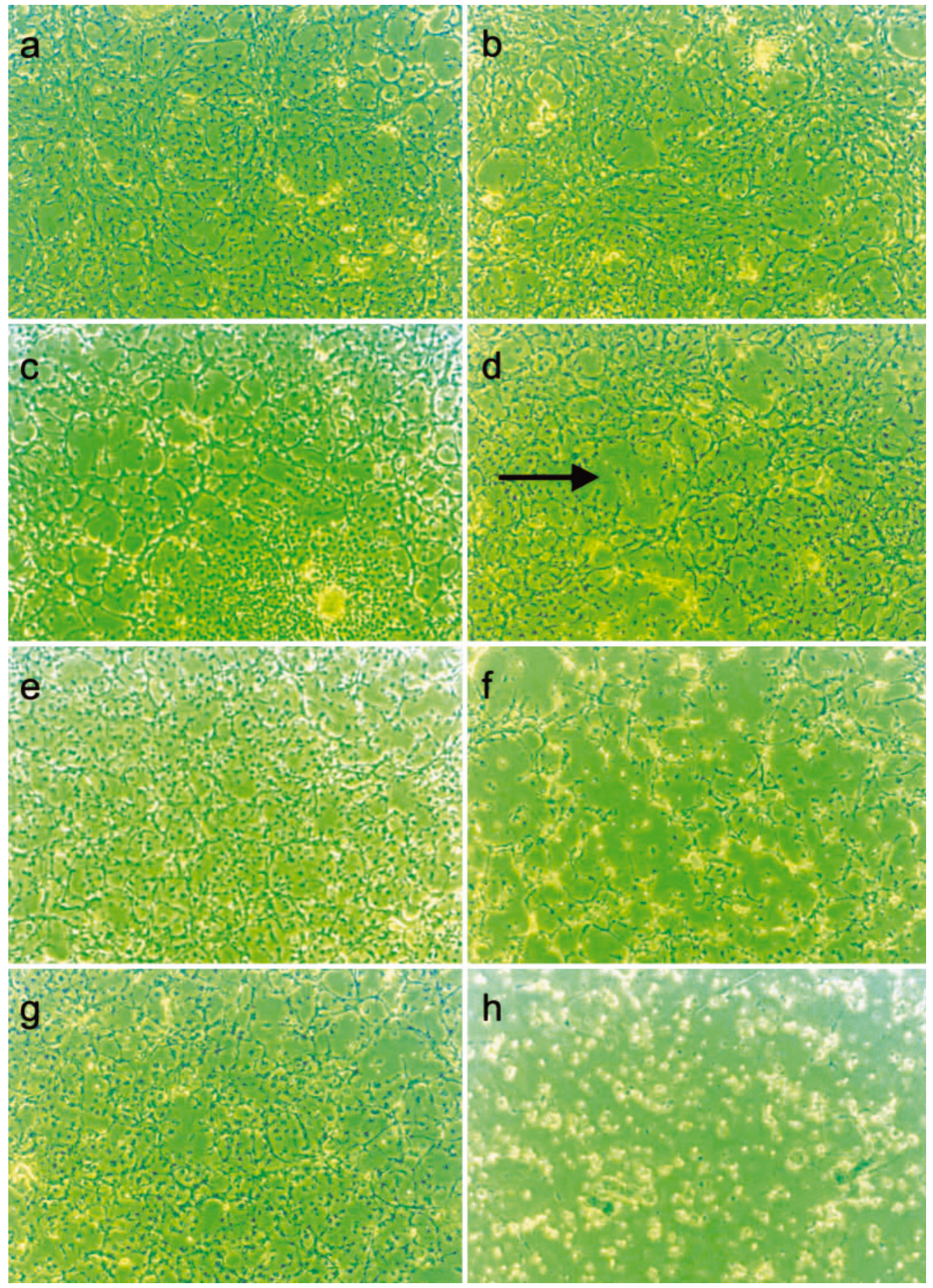

Fig. 2. Penaeus monodon. Propagation of yellow head virus (YHV) in primary cell culture of oka organ. (a,c,e,g) Confluent monolayers of cells inoculated with control medium, and $(\mathrm{b}, \mathrm{d}, \mathrm{f}, \mathrm{h})$ inoculated with YHV; all incubated for $7 \mathrm{~d}$. (a,b) Culture at $1 \mathrm{~d}$, (c,d) at $3 \mathrm{~d},(\mathrm{e}, \mathrm{f})$ at $5 \mathrm{~d},(\mathrm{~g}, \mathrm{~h})$ at $7 \mathrm{~d}$ post-inoculation. Cytopathic effects (arrow in d) were first observed at $3 \mathrm{~d}$ post-inoculation magnification $(\mathrm{a}-\mathrm{h}) \quad 40$

temperature for $90 \mathrm{~min}$. After incubation, $150 \mu \mathrm{l}$ of basal medium was added. The inoculated plate was then incubated at $28 \pm 1^{\circ} \mathrm{C}$ for $7 \mathrm{~d}$. TCID ${ }_{50}$ calculations were made as described by Reed \& Muench (1938).
Results and discussion. While several studies have reported the establishment of primary cell cultures from the oka organ (Chen \& Kou 1989, Nadala et al. 1993, Hsu et al. 1995, Lu et al. 1995b, Tapay et al. 
1995, 1997, Chen \& Wang 1999, Itami et al. 1999, Kasornchandra et al. 1999, Owens \& Smith 1999, Wang et al. 2000), only 1 (West et al. 1999) has provided a quantitative analysis of their growth to confluence. We therefore undertook to determine the growth profile of oka primary cell cultures from initial seeding to confluence.

Primary lymphoid (oka) cell culture: Given that a loss of cell viability has been reported following trypsinization (Itami et al. 1999, Owens \& Smith 1999), the experiment was performed by seeding parallel flasks from a single starting preparation and counting duplicate flasks at each time point. Viable cell number was determined by trypsinizing the cells followed by trypan blue staining and counting cells with a hemocytometer. As the counted cells were not further propagated, the deleterious effect of trypsinization on cell viability was avoided. Fig. 1a shows the growth profiles of 2 independent experiments ( $\mathrm{n}=2$ for each experiment), Fig. $1 \mathrm{~b}$ the combined data of both experiments, with cell number calculated as a percentage of initial number of cells seeded. Both experiments showed very close agreement when numbers were calculated as a percentage of initial numbers of cells. There was an initial drop in cell numbers in both experiments (39.95 and $36.83 \%$, respectively) followed by a relatively constant increase. After confluence, the cells remained viable (with a change of media) for up to $21 \mathrm{~d}$ (data not shown).

Virus amplification and purification: A small amount of viral stock of the yellow head virus was subjected to amplification by passage through healthy prawns. The prawns were pre-screened as negative for both YHV (RT-PCR) and WSSV (PCR). Analysis of the resultant viral stock revealed it to be positive for YHV (RT-RCR) and negative for WSSV (PCR) (data not shown). The stock was further analyzed by SDS-PAGE gel electrophoresis and Western blotting with an antibody directed against the p116 protein of YHV, and by transmission electron microscopy (data not shown). The stock was analyzed for viral titer by an in vitro quantal assay $\left(\right.$ TCID $_{50}$ ).

YHV propagation profile: We infected $25 \mathrm{~cm}^{2}$ flasks of confluent oka primary cell culture with the purified YHV stock at an MOI of 0.001 . We chose this low MOI because it may more accurately reflect the actual exposure of shrimp to the virus in vivo. The cell cultures were examined daily under the microscope, and the onset of CPE was recorded at 3 d post-inoculation. The CPE progressively increased, reaching almost $100 \%$ by Day 7 (Fig. 2h). Aliquots of cell growth-media were taken immediately after inoculation and at daily intervals thereafter. Viral levels were determined by the in vitro quantal methodology of Reed \& Muench (1938), using 96-well plates seeded with suspensions of oka primary cell culture grown to confluence. Combined results from 2 independent experiments $(\mathrm{n}=2$ for each experiment) are shown in Fig. 3. Infective YHV particles were detectable as early as $24 \mathrm{~h}$ postinoculation, with values of 2.314 and $2.661 \log _{10}$ $\mathrm{TCID}_{50} \mathrm{ml}^{-1}$ calculated for the 2 experiments (mean = $2.4875 \log _{10} \mathrm{TCID}_{50} \mathrm{ml}^{-1}$ ). Maximal viral levels occurred at $4 \mathrm{~d}$ post-inoculation (Fig. 3). The levels of the virus on Day 4 represented a 1000-fold increase over initial virus levels, although actual amplification levels may have been higher, since not all the initial viruses were internalized (evidenced by the titer at Day 0). The presence of YHV and the absence of WSSV in the culture medium was confirmed by RTPCR for YHV and PCR for WSSV (data not shown) as well as by Western blotting (Fig. 4). The presence of YHV on Day 1 was confirmed by RT-PCR analysis, although viral levels were too low for Western blot detection before Day 2.

This report documents the production of infectious viral particles within $24 \mathrm{~h}$ of infection, preceding the appearance of cytopathic effects in the primary cells by $48 \mathrm{~h}$. Currently there is no data on the time from infection to signs of disease in naturally infected shrimp. In experimentally infected shrimp, signs of disease similar to those in naturally infected shrimp have been reported to occur 24 to $48 \mathrm{~h}$ after challenge (Boonyaratpalin et al. 1993, Lu et al. 1995a, Wang \& Chang 2000). However, these results were obtained by intramuscular injection of crude preparations of infected organs, and as such possibly represent very high inocula of the virus and may therefore not reflect the situation in vivo.

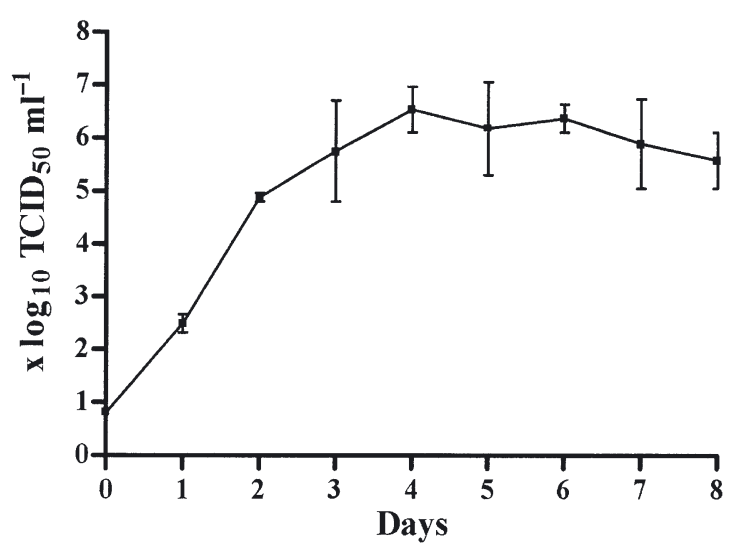

Fig. 3. Penaeus monodon. Profile of yellow head virus propagation in primary culture of oka cells. Data are means $( \pm$ SEM, $\mathrm{n}=2$ ) of 2 independent experiments 

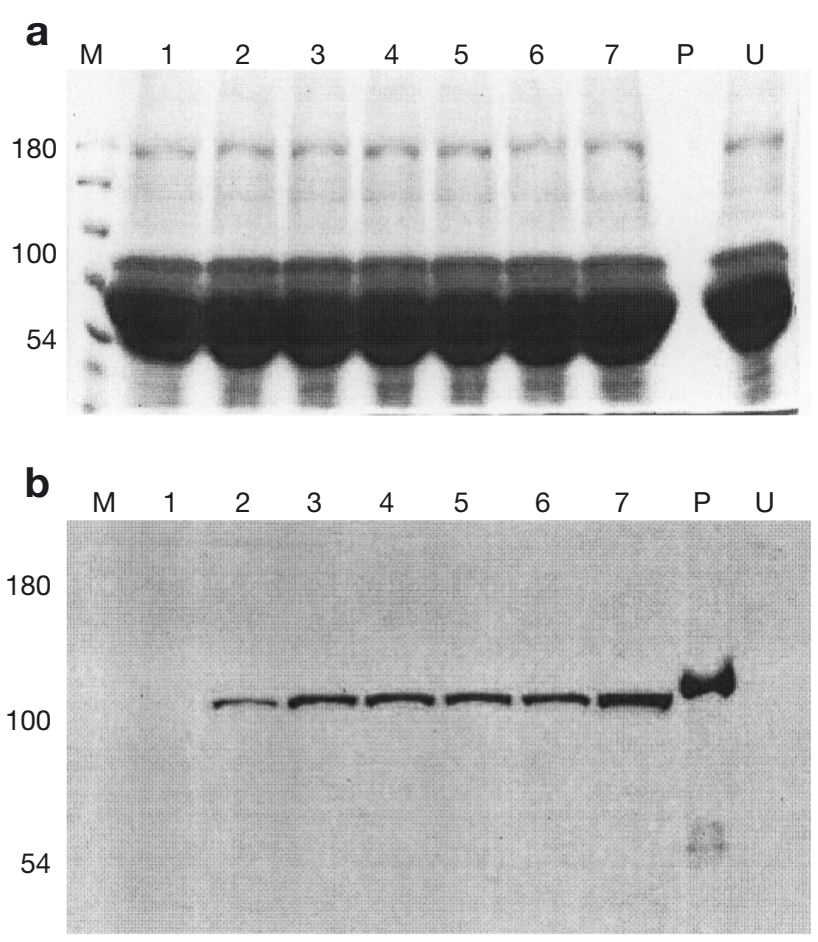

Fig. 4. Penaeus monodon. (a) SDS-PAGE and (b) Western blot analyses of daily aliquots of YHV propagation medium $\mathrm{kDa}$ (a) SDS-PAGE gel analysis. (b) Western blot analysis using antibody directed against YHV p116 protein. M: Protein marker standard lane (kdaltons) (Fermentas); Lanes 1 to 7: 20 $\mu \mathrm{l}$ aliquots of daily growth medium from YHV propagation experiment; P: positive control of purified YHV stock virus; $\mathrm{U}$ : negative control from uninfected cells

Acknowledgements. We are grateful to Dr. Boonsirm Withyachumnarnkul for kindly providing the original stock of yellow head virus. We thank Dr. Jiraporn Kasornchandra and Raewat Khongpradit for advice on primary cell cultures of the lymphoid (oka) organ of Penaeus monodon. This work was supported by the Thailand Research Fund. W.A. is a recipient of a Thailand Research Fund Royal Golden Jubilee Scholarship.

\section{LITERATURE CITED}

Boonyaratpalin S, Supamattaya K, Kasornchandra J, Direkbusaracom S, Aekpanithanpong U, Chantanachooklin C (1993) Non-occluded baculo-like virus, the causative agent of yellow head disease in the black tiger shrimp (Penaeus monodon). Fish Pathol 28:103-109

Chen SN, Kou GH (1989) Infection of cultured cells from the lymphoid organ of Penaeus monodon Fabricius by monodon-type baculovirus (MBV). J Fish Dis 12:73-76

Chen SN, Wang CS (1999) Establishment of cell culture systems from penaeid shrimp and their susceptibility to white spot disease and yellow head viruses. Methods Cell Sci 21:199-206

Chen SN, Chi SC, Kou GH, Liao IC (1986) Cell culture from tissues of grass prawn, Penaeus monodon. Fish Pathol 21: 161-166
Flegel TW (1997) Special topic review: major viral diseases of the black tiger prawn (Penaeus monodon) in Thailand. World J Microbiol Biotechnol 13:433-442

Flegel TW, Boonyaratpalin S, Withyachumnarnkul B (1997) Progress in research on yellow-head virus and white-spot virus in Thailand. In: Flegel TW, MacRae IH (eds) Diseases in Asian Aquaculture. III. Asian Fisheries Society, Manila, p 285-295

Fraser CA, Hall MR (1999) Studies on primary cell cultures derived from ovarian tissue of Penaeus monodon. Methods Cell Sci 21:213-218

Hsu YL, Yang YH, Chen YC, Tung MC, Wu JL, Engelking MH, Leong JC (1995) Development of an in vitro subculture system for the oka organ (lymphoid tissue) of Penaeus monodon. Aquaculture 136:43-55

Itami T, Maeda M, Kondo M, Takahashi Y (1999) Primary culture of lymphoid organ cells and haemocytes of kuruma shrimp, Penaeus japonicus. Methods Cell Sci 21: $237-244$

Kasornchandra J, Khongpradit R, Ekpanithanpong U, Boonyaratpalin S (1999) Progress in the development of shrimp cell cultures in Thailand. Methods Cell Sci 21:231-235

Lightner DV, Hasson KW, White BL, Redman RM (1998) Experimental infection of western hemisphere penaeid shrimp with Asian white spot syndrome virus and Asian yellow head virus. J Aquat Anim Health 10:271-281

Lu Y, Tapay LM, Brock JA, Loh PC (1994) Infection of the yellow head baculo-like virus (YBV) in two species of penaeid shrimp, Penaeus stylirostris (Stimpson) and Penaeus vannamei (Boone). J Fish Dis 17:649-656

Lu Y, Tapay LM, Loh PC, Brock JA, Gose RB (1995a) Distribution of yellow-head virus in selected tissues and organs of penaeid shrimp Penaeus vannamei. Dis Aquat Org 23:67-70

Lu Y, Tapay LM, Loh PC, Brock JA, Gose R (1995b) Development of a quantal assay in primary shrimp cell culture for yellow head baculovirus (YBV) of penaeid shrimp. J Virol Methods 52:231-236

Luedeman RA, Lightner DV (1992) Development of an in vitro primary cell culture system from the penaeid shrimp, Penaeus stylirostris and Penaeus vannamei. Aquaculture 101:205-211

Mohan CV, Shankar KM, Kulkarni S, Sudha PM (1998) Histopathology of cultured shrimp showing gross signs of yellow head syndrome and white spot syndrome during 1994 Indian epizootics. Dis Aquat Org 34:9-12

Nadala EC, Lu Y, Loh PC (1993) Primary culture of lymphoid, nerve, and ovary cells from Penaeus stylirostris and Penaeus vannamei. In Vitro Cell Dev Biol 29A:620-622

Owens L, Smith J (1999) Early attempts at production of prawn cell lines. Methods Cell Sci 21:207-211

Reed LJ, Muench H (1938) A simple method of estimating fifty percent end points. Am J Hyg 27:493-497

Tang KFJ, Lightner DV (1999) A yellow head virus gene probe: nucleotide sequence and application for in situ hybridization. Dis Aquat Org 35:165-173

Tapay LM, Lu Y, Brock JA, Nadala ECB Jr, Loh PC (1995) Transformation of primary cultures of shrimp (Penaeus stylirostris) lymphoid (Oka) organ with simian virus-40 (T) antigen. Proc Soc Exp Biol Med 209:73-78

Tapay LM, Lu Y, Gose RB, Nadala ECB Jr, Brock JA, Loh PC (1997) Development of an in vitro quantal assay in primary cell cultures for a non-occluded baculo-like virus of penaeid shrimp. J Virol Methods 64:37-41

Wang CH, Yang HN, Tang CY, Lu CH, Kou GH, Lo CF (2000) Ultrastructure of white spot syndrome virus development in primary lymphoid organ cell cultures. Dis Aquat Org 41:91-104 
Wang YC, Chang PS (2000) Yellow head virus infection in the giant tiger prawn Penaeus monodon cultured in Taiwan. Fish Pathol 35:1-10

West L, Mahony T, McCarthy F, Watanabe J, Hewitt D, Hansford S (1999) Primary cell cultures isolated from Penaeus monodon prawns. Methods Cell Sci 21:219-223

Wongteerasupaya C, Sriurairatana S, Vickers JE, Akrajamorn

Editorial responsibility: Timothy Flegel,

Bangkok, Thailand
A and 5 others (1995) Yellow-head virus of Penaeus monodon is an RNA virus. Dis Aquat Org 22:45-50

Wongteerasupaya C, Tongchuea W, Boonsaeng V, Panyim S, Tassanakajon A, Withyachumnarnkul B, Flegel TW (1997) Detection of yellow-head virus (YHV) of Penaeus monodon by RT-PCR amplification. Dis Aquat Org 31: 181-186

Submitted: July 2, 2002; Accepted: March 24, 2003

Proofs received from author(s): July 11, 2003 